\title{
Ameliorative Effect of Vitamin $E$ on Biochemical and Ultrastructural Changes in Artemether-induced Renal Toxicity in Rats
}

\author{
Efecto Paliativo de la Vitamina $\mathrm{E}$ sobre los Cambios Bioquímicos y Ultraestructurales \\ en la Toxicidad Renal Inducida por Arteméter en Ratas \\ Refaat A. Eid ${ }^{1}$; Mohamed Samir Ahmed Zaki ${ }^{2,3}$; Mansour A. Alghamd²; \\ Adnan Wares ${ }^{2}$; Muhammad Alaa Eldeen ${ }^{4}$; Ehab El Sayed Massoud ${ }^{5,6}$ \& Mohamed A Haidara ${ }^{7}$
}

EID, R. A.; ZAKI, M. S. A.; ALGHAMD, M. A.; WARES, A.; ELDEEN, M. A.; MASSOUD, E. E. S. \& HAIDARA, M. A. Ameliorative effect of vitamin e on biochemical and ultrastructural changes in artemether-induced renal toxicity in rats. Int. J. Morphol., 38(2):461-471, 2020.

SUMMARY: This experiment was designed to study the administration of normal doses of one of recent antimalarial drug and coadministration of vitamin E on the kidney tissue. A total twenty-four adult male albino rats were used and divided into four groups: the first one served as a control, the second received artemether orally for three days consecutively. The rats of the third and fourth groups received the same dose of artemether concomitantly with 50 and $100 \mathrm{mg} / \mathrm{kg}$ vitamin E orally daily for 2 weeks. After the last dose, the rats were sacrificed and the kidney tissues with blood samples obtained and processed for light, electron microscopic and biochemical analysis. Histologically, artemether treated kidneys showed atrophied glomeruli with widened urinary space and kidney tubules were degenerated with disturbed contour and some vacuoles inside it. Ultrastructurally, the glomeruli of this group showed hypertrophic endothelial cells, irregularity of its basement membrane, disrupted foot processes and filtration slits. The kidney tubule cells showed loss of basal infoldings, cytoplasmic vacuolation, polymorphic damaged swollen mitochondria a loss of its microvilli towards its capillary lumen. Artemether plus vitamin E of the rat kidney groups showed improvement of morphological changes compared to the changes seen in artemether alone. These data were confirmed by biochemical findings with marked improvement of blood urea and creatinine levels and increase of anti-oxidant enzyme activities of glutathione peroxidase and superoxide dismutase in the vitamin $\mathrm{E}$ treated groups. The results of this study revealed that vitamins $\mathrm{E}$ can improve the adverse changes of artemether of rat renal tissue.

KEY WORDS: Artemether; Rats; Vitamin E; Light and electron microscopy; Biomarkers of kidney injury.

\section{INTRODUCTION}

The infection with malaria which is a mosquito borne Plasmodium falciparum parasite is still an important global health problem. The patient usually gets acute febrile illness after a mosquito bite in a malarial area. Treatment of the infected cases requires antimalarial drug administration. Similar to any drug, the adverse effects of antimalarial drugs are evident. (Albay et al., 2005).

Artemesin is a novel sesquiterpene lactone, extracted from the leaves of the shrub that possesses an endoperoxide bridge, which is a rare feature in natural products. Artemesin, from sweet wormwood, and its derivatives have been shown to exert antimalarial activity and have consequently been developed as treatments for malaria caused by the Plasmodium falciparum parasite (Lai et al., 2013). To improve its bioavailability, its derivatives such as artemether which is a methyl ether derivative of artemisinin, artesunate etc., have been developed (Balint, 2001).

Oral administration of artemether in rats was reported to result in adverse effects (Classen et al., 1999; Xiao et al., 2002). The mode of action is that endoperoxide bridge in artemether introduced by free iron decomposed by hemoglobin, produces unstable free radicals and/or other electrophilic intermediates, which form covalent compound with the protein of plasmodia hence killing plasmodia (Meshnick et al., 1989).

\footnotetext{
${ }^{1}$ Pathology department, College of Medicine, King Khalid University, Abha 61421, Saudi Arabia.

${ }^{2}$ Anatomy department, College of Medicine, King Khalid University, Abha 61421, Saudi Arabia.

${ }^{3}$ Histology department, College of Medicine, Zagazig University, Egypt.

${ }^{4}$ Biology Department, Physiology Section, Faculty of Science, Zagazig University, Egypt.

${ }^{5}$ Department of Biology, Faculty of Sciences and Arts in Dahran Aljanoub, King Khalid University, Saudi Arabia.

${ }^{6}$ Agriculture Research Center, Soil, Water and Environment, Egypt.

${ }^{7}$ Physiology department, Kasr al-Aini Faculty of Medicine, Cairo University, Cairo, Egypt.

FUNDING: This research was fully funded by Deanship of Scientific Research at King Khalid University, Abha, KSA (Grant No. G.R.P-281-40).
} 
The urinary system has a major role in the elimination of toxic materials, in filtration, metabolism and deification of xenobiotic or their metabolic products. Chemical materials or their active metabolic types can transfer from plasma to kidney tubules and compared to other tissues can have a manifold concentration. Kidneys should receive $25 \%$ of heart output in order to have a good distribution of chemical materials (Engelking et al., 2012). Kidney is a dynamic organ that represents the major control system maintaining body homeostasis. It possesses an impressive regeneration capacity and it is the most efficient performer among all tissues in the body (Kumar et al., 2004).

Vitamin E (Vit E) has a main role in protecting the body against harmful effects of metabolically active types of oxygen that can have a strong antioxidant function (Eggermont, 2006; Mahan et al., 2012). Vit E, as a membrane stabilizer, is well known as free radical scavenger (Wang et al., 2010) and protects critical cellular structures against oxidative damage caused by oxygen free radicals and reactive products of lipid peroxidation (Arita et al., 1998). Additionally, (Boldyrev et al., 1995) reported that the protective role of VitE against the toxicity of oxidants may be due to the quenching of hydroxyl radicals.

The effect of artemether on the structure of kidney has not been reported so far. There have been no available animal studies conducted on the effect of artemether on the kidney.

\section{MATERIAL AND METHOD}

Animals. Twenty-four adult male albino rats of the Wister strain weighing $200+21 \mathrm{~g}$ were used in this study. Animals were obtained from the animal house, King Khaled University. Food and water were provided "ad libitum". The animals were housed in stainless steel cages with the following room conditions: temperature: $20+5{ }^{\circ} \mathrm{C}$, relative humidity: $50+15$ $\%$, light/dark cycle: $12 \mathrm{~h} / 12 \mathrm{~h}$.

Materials. The chemicals used in this study were purchased from Sigma Chemicals (St. Louis, MO, USA).

Drug administration. Artemether was suspended in corn oil at a concentration of $20 \mathrm{mg} / \mathrm{ml}$ equal to $200 \mathrm{mg} / \mathrm{kg}$ body weight. Drug suspension was prepared fresh daily and stored at $4{ }^{\circ} \mathrm{C}$, protected from light, prior to use. The suspension was administered orally for 3 days at $2 \mathrm{ml}$ daily. The drug suspension was administered by gavage using a plastic syringe fitted with a plastic esophageal tube.

Experimental design and animal grouping: The rats were randomly divided into four groups (six rats each). First group served as a control and received an equal volume of corn oil which used as a solvent for artemether. The rats of the second group were exposed to oral intake of $2 \mathrm{ml}$ artemether for three consecutive days. The rats of the third group received the same dose of artemether concomitantly with $50 \mathrm{mg} / \mathrm{kg}$ vitamin $\mathrm{E}$ ( $\alpha$-tocopherol) dissolved in corn oil by oral gavages daily for 2 weeks. The rats of the fourth group received the same dose of artemether concomitantly with $100 \mathrm{mg} / \mathrm{kg}$ vitamin $\mathrm{E}$ ( $\alpha$-tocopherol) dissolved in corn oil by oral gavages daily for 2 weeks.

Animals were sacrificed after $24 \mathrm{~h}$ following the last dose. The animals were killed by cervical dislocation, their abdomens opened immediately. Kidneys were rapidly dissected under a stereoscopic microscope.

Light microscopy. The kidney was perfused by normal saline followed by $10 \%$ neutral buffered formalin to insure perfect fixation. Three mm specimens from each kidney were cut. Specimens were washed over night with tap water and were then dehydrated through a graded series of ethanol $(50 \%, 60$ $\%, 70 \%, 85 \%, 95 \%$ and $100 \%$ ), 30 minutes for each step. They were incubated in a 50:50 mixture of 100\% ethanol and xylene for 30 minutes and followed by two washes in xylene for $\mid h$. After that, they were transferred to xylene and paraffin embedding mixture for 30 minutes. Transverse sections $(5 \mathrm{~mm})$ were taken and dewaxed under $60^{\circ} \mathrm{C}$. Sections were immersed in xylene for $1 \mathrm{~h}$ and rehydrated through a graded series of ethanol $(100 \%, 95 \%, 80 \%, 70 \%$ and $60 \%)$ for 2 minutes in each concentration and were then washed in tap water (Drury\& Wallington, 1980). They were stained with hematoxylin and eosin (H\&E). Slides were mounted using Entellan embedding agent and covered with cover slips prior to viewing and photography under the Olympus light microscope provided by digital camera connected to computer.

Transmission electron microscopy (TEM): For TEM, kidney specimens from both control and treated rats were immediately preserved in $2.5 \%$ glutaraldehyde, trimmed and diced into 1 cubic millimeter sizes, fixed in glutaraldehyde solution in $0.1 \mathrm{M}$ sodium cacodylate buffer, $\mathrm{pH} 7.2$, and placed in a thermal box cooled to $4{ }^{\circ} \mathrm{C}$ for $2 \mathrm{~h}$. They were post-fixed in $1 \%$ osmium tetroxide in a sodium cacodylate buffer and then dehydrated in ascending series of ethyl alcohol and embedded in Spur's resin. Ultrathin sections stained with uranyl acetate and lead citrate were examined by TEM (JEM1011, Jeol Co., Japan) operated at $80 \mathrm{KV}$ in the Electron Microscopy Unit, Pathology Department, College of Medicine, King Khalid University (Eid et al., 2017).

Biochemical study. Blood samples were collected in nonheparinized tubes for biochemical analysis of various kidney function to detect levels of creatinine and blood urea. 
Antioxidant status in kidney homogenate: Kidney specimens were homogenized in $100 \mathrm{mM}$ tris- $\mathrm{HCl}(\mathrm{pH} 7.4)$ and centrifuged at $12,000 \times \mathrm{g}$ at $4^{\circ} \mathrm{C}$. Supernatant was used for the estimation of renal antioxidant parameters including glutathione peroxidase (GPx) and superoxide dismutase (SOD) activity. Renal GPx and SOD were measured by colorimetric methods.

Statistical analysis. For all groups, the data were expressed as mean $\pm \mathrm{SD}(\mathrm{X} \pm \mathrm{SD})$. The data obtained from the image analyzer and the biochemical data were subjected to SPSS program version 14 (Chicago, Illinois, USA). Statistical analysis using the one-ay analysis of variance test was carried out. The results were considered statistically significant as $P$ value was less than 0.05 .

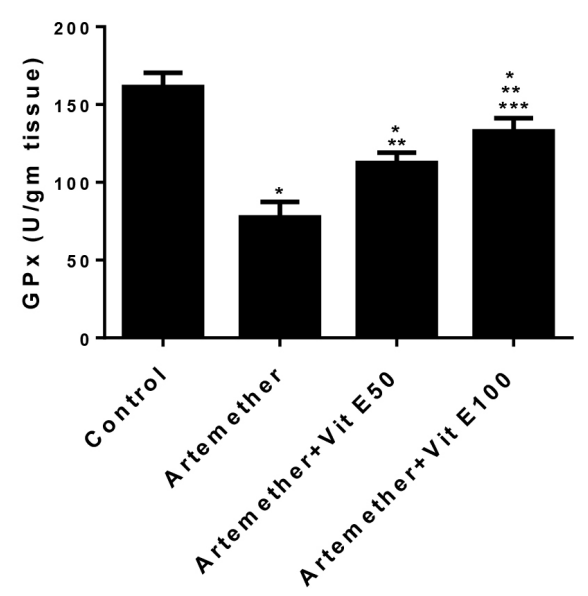

A

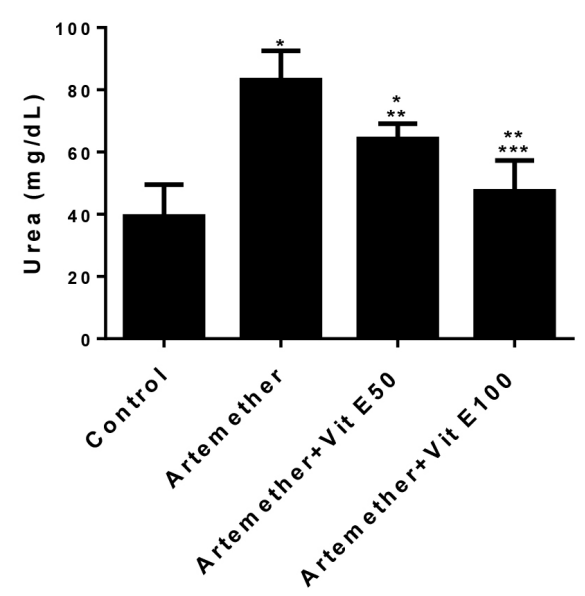

\section{RESULTS}

Biochemical study. In the present study, there was a significant increase $(\mathrm{p}<0.05)$ in the blood urea and serum creatinine $(\mathrm{mg} / \mathrm{dl})$ levels in artemether group as compared to the control group levels. Marked improvement of blood urea and creatinine levels in the vitamin $\mathrm{E}$ treated groups were observed (Fig. 1, C and D). The activities of glutathione peroxidase (GPx) and superoxide dismutase (SOD) levels in artemether group decreased significantly $(p<0.05)$ as compared with the controls. We found a significant increase of anti-oxidant enzyme activities of SOD and GPx levels in vitamin E recipient groups versus artemether rats (Fig. 1, A and B).

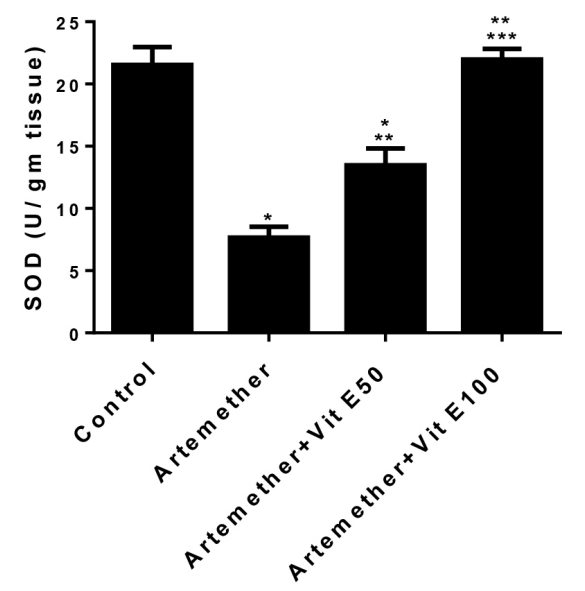

B

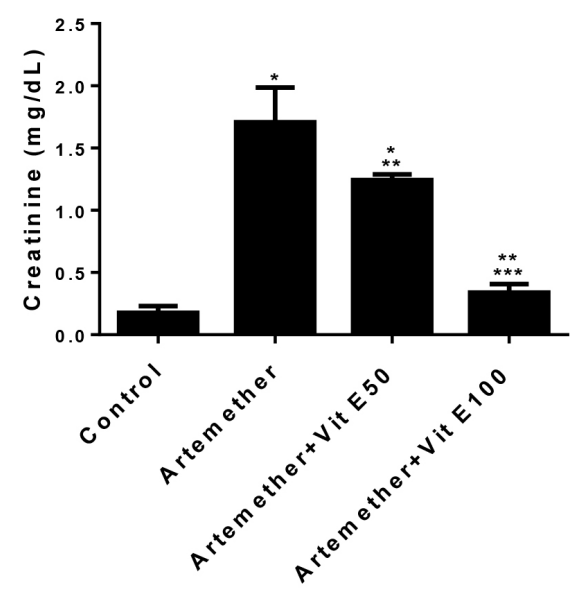

C

Fig. 1. A significant increase in the blood urea and serum creatinine $(\mathrm{mg} / \mathrm{dl})$ levels in artemether group as compared to the control group levels. Marked improvement of blood urea and creatinine levels in the vitamin E treated groups were observed (C and D). The activities of SOD and GPx levels in artemether group decreased significantly as compared with the controls. We found a significant increase of anti-oxidant enzyme activities (SOD and GPx) levels in vitamin E recipient groups versus artemether rats (A and B). 
Light microscopic study. The microscopic hematoxylin and eosin histology slides of kidney in the control group showed normal cellular structure with intact glomeruli and regular tubular contour. There were no signs of necrosis or cellular damage (Fig. 2A).

Atrophied glomeruli with widened urinary space and degenerated tubules were seen in the treated group with artemether with disturbed their contour with some vacuoles inside it plus interstitial blood accumulation (Fig. 2B).
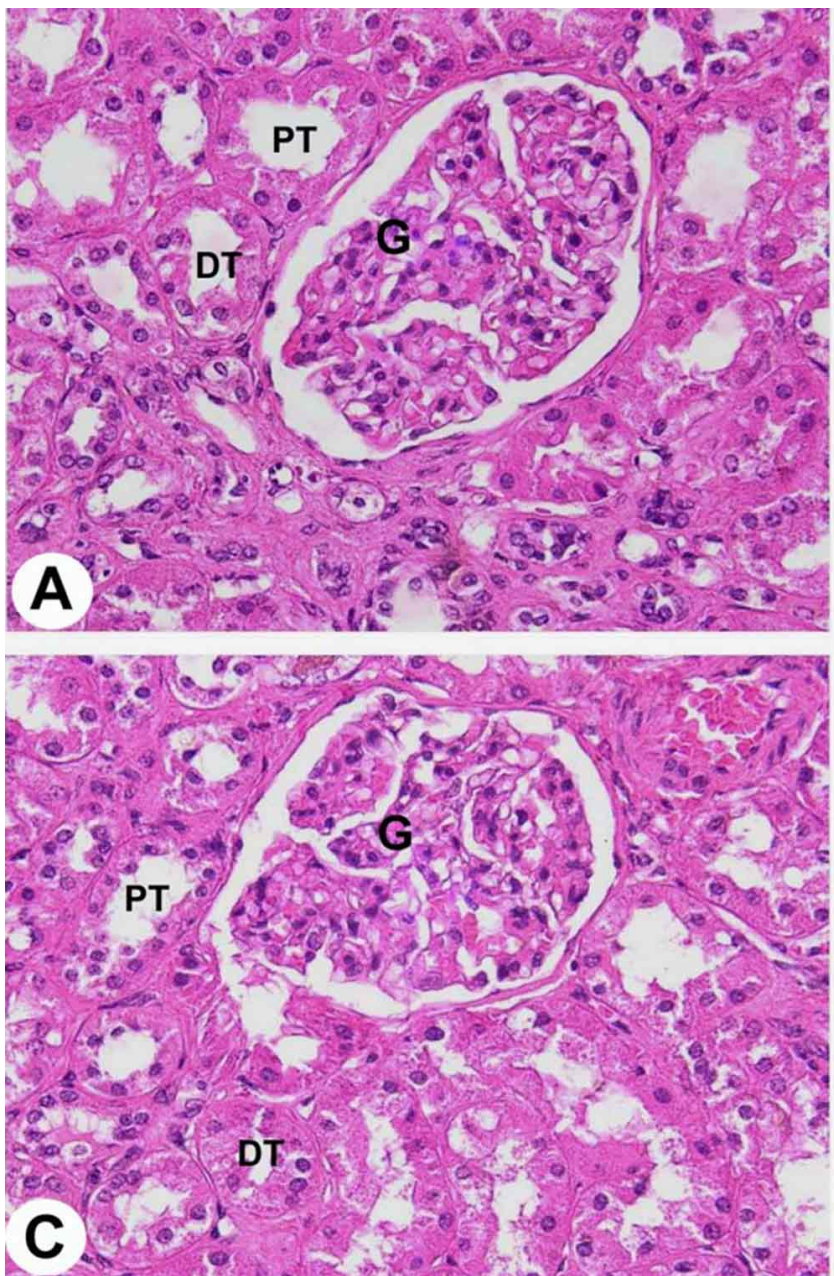

Fig. 2. Hematoxylin and eosin micrographs of the kidney groups (A). A photomicrograph of a section in the rat kidney of the control group showing normal cellular structure with intact glomeruli and regular tubular contour. There were no signs of necrosis or cellular damage. The renal glomeruli $(\mathrm{G})$ with tuft of capillaries and normal glomeruli capsule are seen. Notice the contour of the proximal (PT) and distal (DT) convoluted tubules is intact and regular with intact nuclei. (H\&E; X 400). (B): The microscopic hematoxylin and eosin histology slides of kidney for toxicity assessment of selected rat of the artemether treated group showing atrophied glomeruli $(\mathrm{G})$ with widened urinary space and degenerated tubules are seen with disturbed their contour $(\mathrm{T})$ with some vacuoles inside it plus interstitial blood accumulation. (H\&E; X 400). (C): A photomicrograph of a section in the rat kidney of the third group received artemether plus low dose of vitamin E showing some improvement in the glomeruli (G) and proximal (PT) and distal (DT) convoluted tubules. Note, some disrupted glomeruli capsule and minor changes in the tubules in their contours and nuclei are noticed. (H\&E; X 400). (D): A photomicrograph of a section in the rat kidney of the fourth group received artemether plus high dose of vitamin E showing marked improvement in the glomeruli (G) with its glomeruli capsule and proximal (PT) and distal (DT) convoluted tubules contours and intact nuclei. (H\&E; X 400). 


\section{Ultrastructure studies}

Control Group: The kidney of the control group rats showed glomeruli with its capillary lumen a basement membrane and endothelial cell, a visceral epithelial cell with foot processes, glomeruli capsule (Glomeruli's capsule) and mesangial cell, filtration slits and intact clear urinary space (Figs. 3A and 3B). The electron microscope study of this work of a proximal convoluted tubule of the same group kidney showed a basement membrane with basal infoldings, numerous intact mitochondria and a round nucleus with natural distribution of its chromatin content. Apical surface shows long microvilli forming a brush border towards the
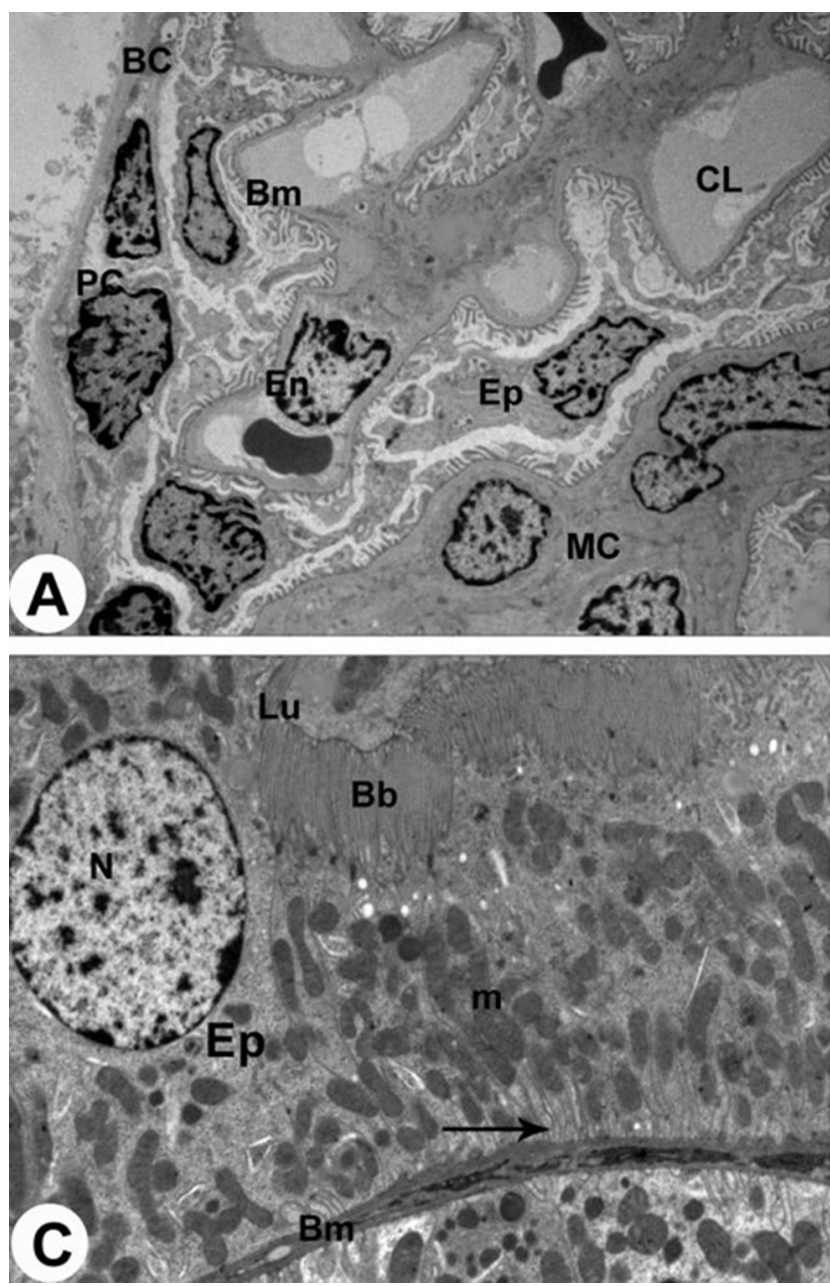

lumen (Fig. 3C). The distal convoluted tubule of the control kidney showed a basement membrane, short microvilli, a rounded nucleus, numerous intact mitochondria and clear lumen (Fig. 3D).

Artemether - treated group: Ultrastructural study of the artemether treated rats showed marked irregularity of the basement membrane, hypertrophic endothelial cells in the capsular space, marked enlargement of the nucleus and increased content of its heterochromatin, many vacuoles appear in its lumen, disrupted foot processes of a visceral epithelial cell and disrupted filtration slits (Figs. 4A and 4B). The proximal convoluted tubule epithelial cell showed loss
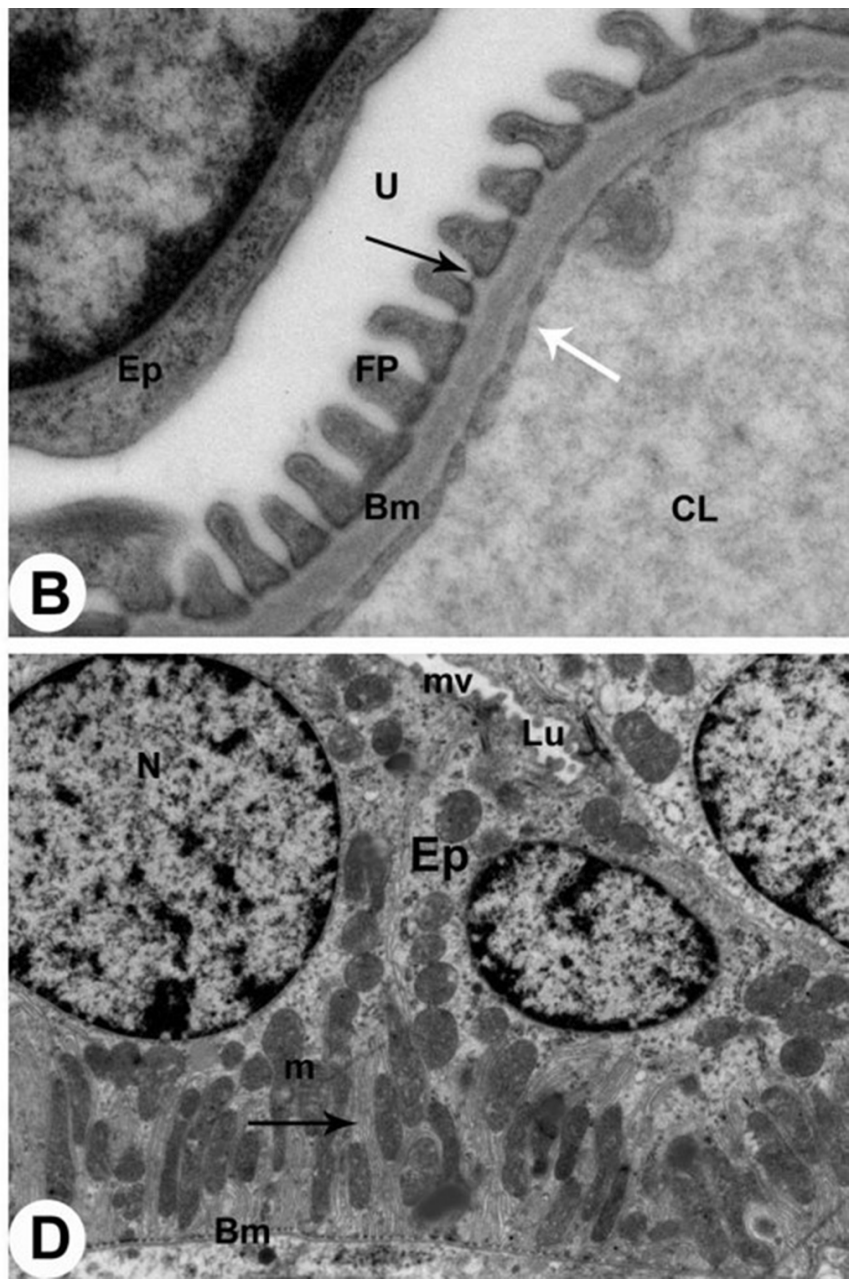

Fig. 3. Control kidney electron micrographs. (A): An electron micrograph of the kidney glomerulus of the control kidney showing its capillary lumen (CL), a basement membrane (BM), endothelial cell (En), a visceral epithelial cell (EP) with foot processes, glomeruli capsule (BC) and mesangial cell (MC). (X 5000). (B): An electron micrograph with higher magnification of the control kidney glomerulus showing its capillary lumen (CL) with its basement membrane (BM), a visceral epithelial cell (Ep) with foot processes (FP), filtration slits (arrow) and intact clear urinary space (U). (X 20000). (C): An electron micrograph of a proximal convoluted tubule epithelial cell (Ep) of the control kidney showing a basement membrane (Bm) with basal infoldings (arrow), numerous intact mitochondria (M) and a round nucleus $(\mathrm{N})$ with natural distribution of its chromatin content. Apical surface shows long microvilli forming a brush border (Bb) towards the lumen (Lu). (X 10000). (D): An electron micrograph of a distal convoluted tubule epithelial cell (Ep) of the control kidney showing a basement membrane $(\mathrm{Bm})$, short irregular microvilli (arrows), a round nucleus $(\mathrm{N})$, numerous intact mitochondria $(\mathrm{M})$ and lumen (Lu). (X 15000). 

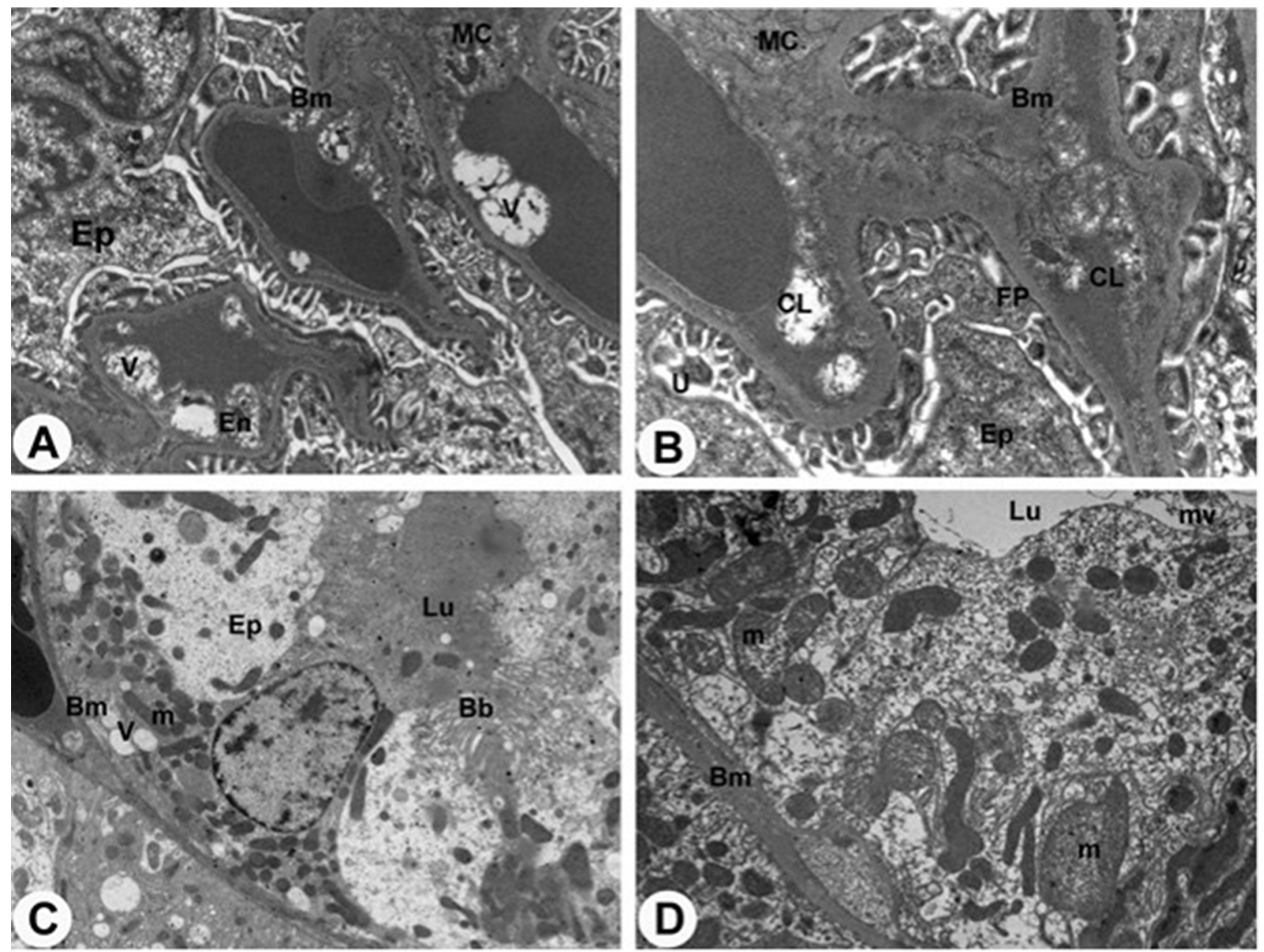

Fig. 4. Treated kidney with artemether. (A): An electron micrograph of a glomerular basement membrane (Bm) of artemether treated rats showing marked irregularity of the basement membrane and hypertrophic endothelial cells (En) in the capsular space with marked enlargement of the nucleus and increased content of its heterochromatin and many vacuoles appear in its lumen. Note the presence of mesangial cell (Mc) in the corner of the graph. (X 10000). (B) An electron micrograph with higher magnification of the control kidney glomerulus showing its capillary lumen (Lu) with marked irregularity of its basement membrane (BM), a visceral epithelial cell (EP) with disrupted foot processes (FP), filtration slits (arrow) and intact clear urinary space (U). Note the presence of mesangial cell (Mc) in the corner of the graph. (X 20000). (C): An electron micrograph of a proximal convoluted tubule epithelial cell (Ep) in artemether treated rats showing loss of cell boundaries and basal infoldings and cytoplasmic vacuolation (V) with polymorphic damaged swollen mitochondria $(\mathrm{M})$ and loss of its brush border $(\mathrm{Bb})(\mathrm{M})$ towards its capillary lumen (Lu). (X 10000). (D): An electron micrograph of kidney in artemether treated rats showing a distal convoluted tubule epithelial cell (Ep) with herniations of its luminal border (Lu). Note the presence of scattered swollen mitochondria (M), thickened basement membrane (Bm) and loss of its microvilli (Mv). (X 15000).

of cell boundaries and basal infoldings and cytoplasmic vacuolation with polymorphic damaged swollen mitochondria and loss of its brush border towards its capillary lumen (Fig. 4C). The distal convoluted tubule showed herniations of its luminal border, scattered swollen mitochondria, thickened basement membrane and loss of its microvilli (Fig. 4D).

Artemether plus low dose of vitamin E: The glomerular basement membrane of artemether plus low dose of vitamin
E rats showed some irregularity of the basement membrane and endothelial cells with a visceral epithelial cell with disrupted foot processes space (Figs. 5A and 5B). The proximal convoluted tubule epithelial cell showed cell boundaries and some basal infoldings starts to be seen and lysosomes with scattered mitochondria and clear brush border towards its capillary lumen (Fig. 5C). The distal convoluted tubule showed its luminal border, scattered mitochondria; basement membrane, intact microvilli and basal infoldings (Fig. 5D). 

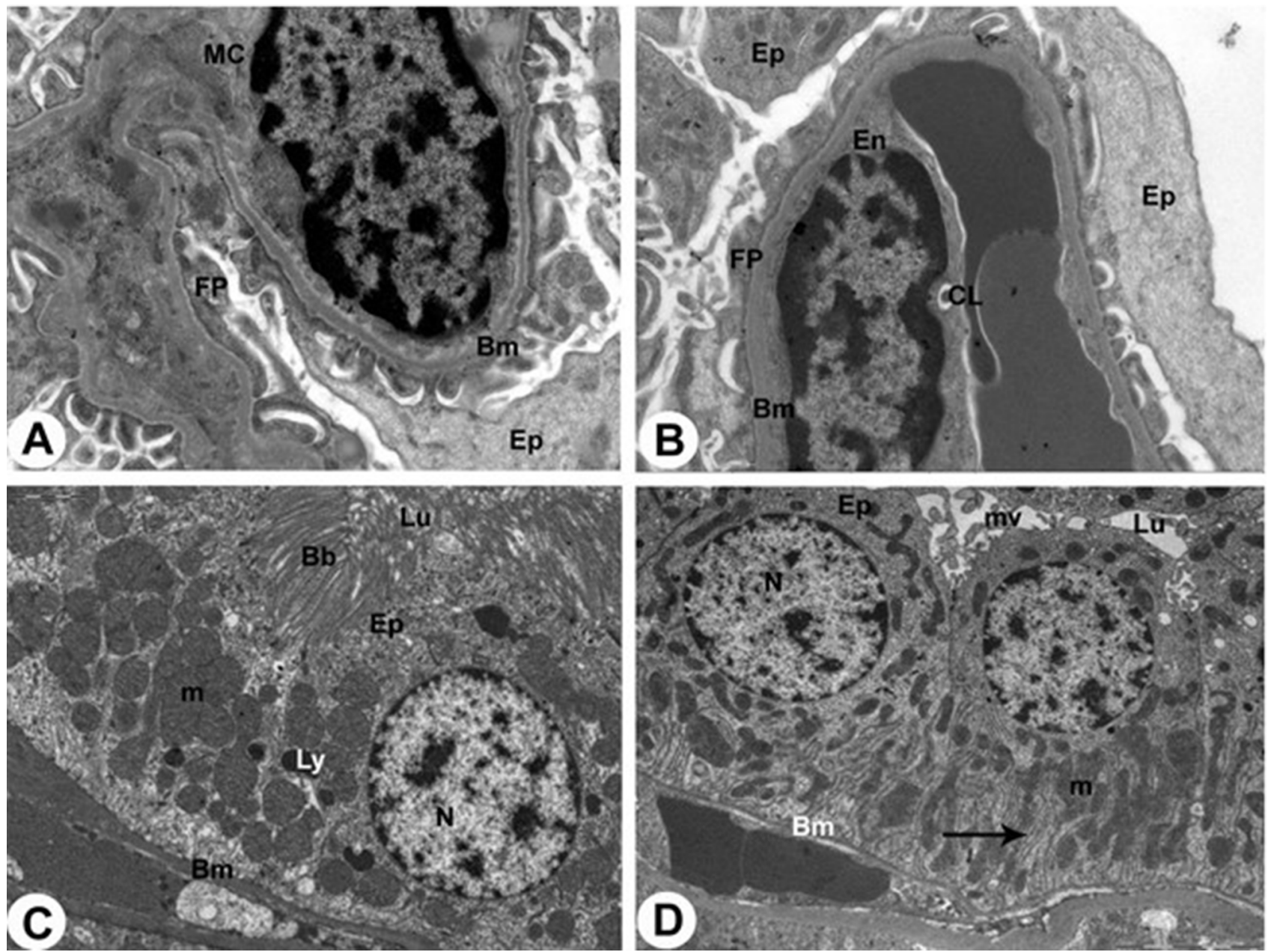

Fig. 5. Artemether plus low dose of vitamin E. (A): An electron micrograph of a glomerular basement membrane (Bm) of artemether plus low dose of vitamin E rats showing some irregularity of the basement membrane and endothelial cells (En) with a visceral epithelial cell (EP) with disrupted foot processes (FP). Note the presence of mesangial cell (Mc) with its nucleus in the corner of the graph. (X 20000). (B) An electron micrograph with higher magnification of artemether plus low dose of vitamin E rat glomerulus showing its capillary lumen $(\mathrm{Lu})$ that filled with blood, endothelial cells (En) some irregularity of its basement membrane (BM), a visceral epithelial cell (EP) and disrupted foot processes (FP). (X 20000). (C): An electron micrograph of a proximal convoluted tubule epithelial cell (Ep) in artemether plus low dose of vitamin E rats showing cell boundaries and some basal infoldings starts to be seen and lysosomes (Ly) with scattered mitochondria $(\mathrm{M})$ and clear brush border $(\mathrm{Bb})$ towards its capillary lumen (Lu). (X 15000). (D): An electron micrograph of kidney epithelial cells in artemether plus low dose of vitamin E rats showing a distal convoluted tubule epithelial cell (Ep) with its luminal border $(\mathrm{Lu})$. Note the presence of scattered mitochondria (M), basement membrane $(\mathrm{Bm})$ and intact microvilli (Mv). Note the presence of basal infoldings (arrow). (X 10000).

Artemether plus high dose of vitamin E: All electron micrographs of the rat kidney showing less morphological changes compared to the changes seen in artemether alone (Figs. 6A-D).

\section{DISCUSSION}

The main objective of this research was to determine the possible protective effect of vitamin $E$ against artemetherinduced nephrotoxicity in the rat model.
The microscopic examination of hematoxylin and eosin histology slides of kidney for toxicity assessment of selected rat of the artemether treated group showed atrophied glomeruli with widened urinary space and kidney tubules were degenerated with disturbed contour and some vacuoles inside it plus interstitial blood accumulation. Glomerular capsule and vessel loops damage were also observed in nephrotic syndrome due to excessive protein loss via the damaged glomerular filtration barrier (Hall et al., 1986; Tesar et al., 1994). Moreover, Rao et al. (2017) found also focal tubular dilation, flattening and attenuation of the epithelium, loss of the luminal brush border, apoptotic tubular 

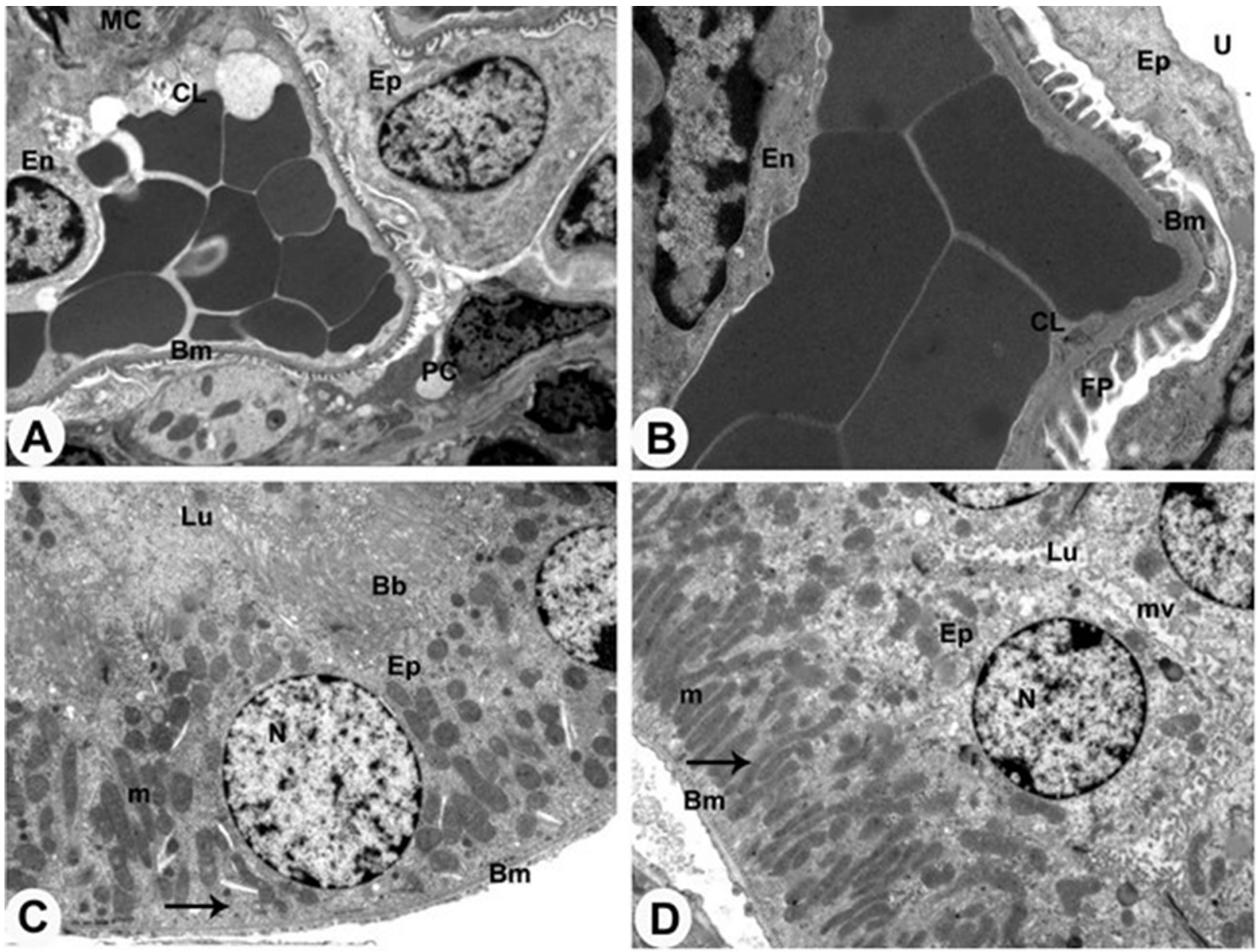

Fig. 6. Artemether plus high dose of vitamin E. All electron micrographs (A-D) of the rat kidney showing less morphological changes compared to the changes seen in artemether alone.

cells, luminal necrotic debris and loss of renal parenchyma with ghost outlines of cells and structures.

This is can explained by, artemether induced oxidative stress, resulting in generation of reactive oxygen species (ROS) which plays a critical role in the initiation and progression of fibrotic diseases (Barnes \& Gorin, 2011). The increased ROS in rat kidney causes the degradation of its inhibitor nuclear factor of kappa light polypeptide gene enhancer in B-cells inhibitor, alpha (IkB-alpha), and free dimmers which stands for nuclear factor kappa-light-chainenhancer of activated B cells (NF-kB) translocate to nucleus and activate the target anti-inflammatory genes (Ansari et al., 2016). The renal tubular epithelia could be exposed to injurious chemical species when molecules appear in the urinary space because of the loss of glomerular permeability. Among these macromolecules are hemoglobin and myoglobin (Zager \& Burkhart, 1997).
Ultrastructurally, this group of rats showed marked irregularity of the endothelial basement membrane, hypertrophic endothelial cells in the capsular space and the visceral epithelial cell showed disrupted foot processes and filtration slits. Recent advances in renal pathophysiology strongly suggest that the diffuse expansion of the mesangial region, may play a critical role in the obliteration of the capillary lumen, leading to a reduction in the surface area available for filtration and ultimate cessation of glomerular function in various forms of glomerulopathy (Quezada et al., 2013). On the other hand, some glomeruli were atrophied with a dilated capsular space; this agreed with the result obtained by other authors (Markowitz et al., 2000), who described this shrunken glomerulus as a sclerotic one.

The proximal convoluted tubule epithelial cell showed loss of basal infoldings and cytoplasmic vacuolation with polymorphic damaged swollen 
EID, R. A.; ZAKI, M. S. A.; ALGHAMD, M. A.; WARES, A.; ELDEEN, M. A.; MASSOUD, E. E. S. \& HAIDARA, M. A. Ameliorative effect of vitamin e on biochemical and ultrastructural changes in artemether-induced renal toxicity in rats. Int. J. Morphol., 38(2):461-471, 2020.

mitochondria with loss of its brush border towards its capillary lumen. Moreover, the distal convoluted tubule epithelial cell showed scattered swollen mitochondria, thickened basement membrane and loss of its microvilli. The basement membranes of the convoluted appeared thickened as well. These signs suggest the presence of lipid peroxidation and the production of free radicals, which destroy the lipid and protein structure of intracellular membranes and hydrolyze the cytoplasm (Saadi et al., 2008).

In addition, apoptotic nuclear changes with fragmented nuclear envelop, thick basement membrane with few basal infoldings, small sized degenerated mitochondria, many lysosomes and cytoplasmic vacuoles were seen by Nasr \& Saleh (2014). Cytoplasmic inclusions were prominent on electron microscopy allowed their morphological characterization as fibrils in cellular lysosomes wrapped by a single membrane. The fibrillary structures observed by using electron microscopy strongly suggested the presence of plasma cell dyscrasia (Herrera, 2007). Devarajan (2005) added that lack of oxygen during ischemia leads to suppression of mitochondrial oxidative phosphorylation resulting in impaired ATP synthesis and decrease activity of cellular energy dependent processes which could contribute to cell death. ATP depletion stops pumping calcium out of the cell. Therefore, calcium accumulates in the cell causing cellular toxicity.

The accumulation of macrophages and inflammatory cells within the interstitial space plays a pathogenic role in the development of tubular injury and interstitial fibrosis (Vielhauer et al., 2001). Proximal tubular epithelial cells are thought to mediate the interstitial macrophage infiltration because of their anatomic position and their ability to produce chemotactic cytokines, chemokines, and other inflammatory mediators. The antimalarial and toxic properties of effective artemisinin agents are dependent on the presence of an endoperoxide bridge; artemisinin agents lacking this bridge, a known source of oxygen free radicals, are devoid of antimalarial and toxic activities (Klayman, 1985; Brossi et al., 1988).

Artemether do not act like a typical oxidant drug that causes promiscuous damage to proteins, nucleic acids and lipids (Halliwell \& Gutteridge, 1999). Unlike most other oxidant drugs, artemether cannot be cyclically oxidized and reduced (Zhang et al., 1992), only one free radical can result from one drug molecule, and all the oxidant end products observed experimentally were observed at very high drug concentrations (Scott et al., 1989; Berman \& Adams, 1997; Meshnick, 2002). Numerous in vitro and in vivo studies have demonstrated that reactive oxygen metabolites including superoxide (free radicals) and hydroxyl radicals are implicated in druginduced acute renal failure (Du \& Yang, 1994; Baliga et al., 1999; Walker et al., 1999).

In the current study, sections of artemether plus vitamin $\mathrm{E}$ (Vit E) treated groups showed improvement in the histological structure of renal glomeruli and renal tubules. The present study results as well as the results of previous studies showed that vitamin $\mathrm{E}$ as an antioxidant can reduce ROS levels in the kidneys (Derakhshanfar et al., 2007).

Vit E can protect body organs such as the kidneys (Karabulut-Bulan et al., 2008), suppress the damage of free radicals in cell membranes (Shamsi et al., 2010) and improve antioxidant enzyme activity in kidney tissues (Derakhshanfar et al.). Vit $\mathrm{E}$ as a powerful antioxidant and is the first line of defense against the peroxidation of fatty acids in phospholipids of cell membranes (Uz \& Uygun, 2005).

In the present study, a significant increase in the blood urea and serum creatinine $(\mathrm{mg} / \mathrm{dl})$ levels in artemether group as compared to the control group levels. Marked improvement of blood urea and creatinine levels in the vitamin $\mathrm{E}$ treated groups were observed. The activities of SOD and GPx levels in artemether group decreased significantly as compared with the controls. We found a significant increase of anti-oxidant enzyme activities of SOD and GPx levels in vitamin E recipient groups versus artemether rats. Spek et al. (2010) concluded that ROS post ischemic reperfusion results in lipid peroxidation which increase permeability of renal tubular cell membranes. Bonventre \& Yang (2011) found that increased production of ROS and induction of proinflammatory cytokines are important constituent in the acute tubular necrosis post ischemic reperfusion injury.

\section{CONCLUSION}

The results of this study revealed that administration of vitamin E can reduce the harmful effects of artemether and improve the adverse changes on rat renal tissue in the treated group compared to the control group.

\section{ACKNOWLEDGEMENTS}

The authors would like to thank the Deanship of scientific research at King Khalid University for supporting the funding of this study. 
EID, R. A.; ZAKI, M. S. A.; ALGHAMD, M. A.; WARES, A.; ELDEEN, M. A.; MASSOUD, E. E. S. \& HAIDARA, M. A. Efecto paliativo de la vitamina $\mathrm{E}$ sobre los cambios bioquímicos y ultraestructurales en la toxicidad renal inducida por arteméter en ratas. Int. J. Morphol., 38(2):461-471, 2020.

RESUMEN: Este proyecto fue diseñado para estudiar la administración de dosis normales de uno de los medicamentos antipalúdicos y de la administración de vitamina $\mathrm{E}$ en el tejido renal. Se utilizaron 24 ratas albinas machos adultas divididas en cuatro grupos: el primero sirvió como control, el segundo recibió arteméter por vía oral durante tres días consecutivos. Las ratas del tercer y cuarto grupos recibieron la misma dosis de arteméter concomitantemente con 50 y $100 \mathrm{mg} / \mathrm{kg}$ de vitamina E por vía oral diariamente durante 2 semanas. Después de la última dosis, las ratas fueron sacrificadas y se obtuvo el tejido renal de cada muestra los cuales fueron procesados para análisis con microscopías de luz y electrónica, además de exámenes bioquímicos. Histológicamente, los riñones tratados con arteméter mostraron atrofia glomerular con espacio urinario ensanchado y túbulos renales degenerados con contorno alterado y algunas vacuolas en su interior. Ultraestructuralmente, los glomérulos de este grupo mostraron células endoteliales hipertróficas, irregularidad de su membrana basal, procesos alterados del pie y hendiduras de filtración. Las células del túbulo renal mostraron pérdida de inflexiones basales, vacuolación citoplasmática, mitocondrias dañadas y pérdida de sus microvellosidades hacia la luz capilar. Arteméter más vitamina E en los grupos de riñón de rata mostraron una mejora de los cambios morfológicos, en comparación con los cambios observados en arteméter solamente. Estos datos fueron confirmados por hallazgos bioquímicos con una marcada mejoría de los niveles de urea y creatinina en sangre y un aumento de las actividades enzimáticas antioxidantes de la glutatión peroxidasa y la superóxido dismutasa en los grupos tratados con vitamina E. Los resultados de este estudio revelaron que la vitamina $\mathrm{E}$ puede mejorar los cambios adversos del arteméter del tejido renal de la rata.

PALABRAS CLAVE: Arteméter; Ratas; Vitamina E; Microscopía de luz y electrónica; Biomarcadores de daño renal.

\section{REFERENCES}

Albay, D.; Adler, S. G.; Philipose, J.; Calescibetta, C. C.; Romansky, S. G. \& Cohen, A. H. Chloroquine-induced lipidosis mimicking Fabry disease. Mod. Pathol., 18(5):733-8, 2005.

Ansari, M. A.; Raish, M.; Ahmad, A.; Ahmad, S. F.; Mudassar, S.; Mohsin, K.; Shakeel, F.; Korashy, H. M. \& Bakheet, S. A. Sinapic acid mitigates gentamicin-induced nephrotoxicity and associated oxidative/nitrosative stress, apoptosis, and inflammation in rats. Life Sci., 165:1-8, 2016.

Arita, M.; Sato, Y.; Arai, H. \& Inoue, K. Binding of atocopherylquinone, an oxidized form of a-tocopherol, to glutathione S-transferase in the liver cytosol. FEBS Lett., 436:424-6, 1998.

Baliga, R.; Ueda, N.; Walker, P. D. \& Shah, S. V. Oxidant mechanism in toxic acute renal failure. Drug Metab. Rev., 31(4):971-97, 1999.

Balint, G. A. Artemisinin and its derivatives: an important new class of antimalarial agents. Pharmacol. Ther, 90(2-3):261-5, 2001.
Barnes, J. L. \& Gorin, Y. Myofibroblast differentiation during fibrosis: role of NAD(P)H oxidases. Kidney Int., 79(9):944-56, 2011.

Berman, P. A. \& Adams, P. A. Artemisinin enhances heme-catalysed oxidation of lipid membranes. Free Radic. Biol. Med., 22(7):1283-8, 1997.

Boldyrev, A. A.; Bulygina, E. R.; Volynskaia, E. A.; Kurella, E. G. \& Tiulina, $\mathrm{O}$. V. The effect of hydrogen peroxide and hypochlorite on brain $\mathrm{Na}, \mathrm{K}-$ ATPase activity. Biokhimiia, 60(10):1688-96, 1995.

Bonventre, J. V. \& Yang, L. Cellular pathophysiology of ischemic acute kidney injury. J. Clin. Invest., 121(11):4210-21, 2011.

Brossi, A.; Venugopalan, B.; Dominguez-Gerpe, L.; Yeh, H. J.; FlippenAnderson, J. L.; Buchs, P.; Luo, X. D.; Milhous, W. \& Peters, W. Arteether, a new antimalarial drug: synthesis and antimalarial properties. J. Med. Chem., 31(3):645-50, 1988.

Classen, W.; Altmann, B.; Gretener, P.; Souppart, C.; Skelton- Stroud, P. \& Krinke, G. Differential effects of orally versus parenterally administered qinghaosu derivative artemether in dogs. Exp. Toxicol. Pathol., 51(6):507-16, 1999

Derakhshanfar, A.; Bidadkosh, A. \& Kazeminia, S. Vitamin E protection against gentamicin-induced nephrotoxicity in rats: a biochemical and histopathologic study. Iran. J. Vet. Res., 8(3):231-8, 2007.

Devarajan, P. Cellular and molecular derangements in acute tubular necrosis. Curr. Opin. Pediatr., 17(2):193-9, 2005.

Drury, R. A. B. \& Wallington, E. A. Carleton`s Histological Technique. 5th ed. Oxford, Oxford University Press, 1980.

Du, X. H. \& Yang, C. L. Mechanism of gentamicin nephrotoxicity in rats and the protective effect of zinc-induced metallothionein synthesis. Nephrol. Dial. Transplant., 9 Suppl. 4:135-40, 1994.

Eggermont, E. Recent advances in vitamin E metabolism and deficiency. Eur. J. Pediatr., 165(7):429-34, 2006.

Eid, R. A.; Al-Shraim, M.; El-Sayed, F. \& Radad, K. Ultrastructural changes of kidney in schistosoma mansoni-infected mice. Ultrastruct. Pathol., 41(5):320-6, 2017.

Engelking, L. R. Metabolic and Endocrine Physiology. $3^{\text {rd }}$ ed. Jackson (WY), Teton NewMedia, 2012.

Hall, R. L.; Wilke, W. L. \& Fettman, M. J. The progression of adriamycininduced nephrotic syndrome in rats and the effect of captopril. Toxicol. App. Pharmacol., 82(1):164-74, 1986.

Halliwell, B. \& Gutteridge, J. M. Free Radicals in Biology and Medicine. Oxford, Clarendon Press, 1999.

Herrera, A. M. Heptinstall's Pathology of the Kidney. Philadelphia (PA), Lippincott Williams \& Wilkins, 2007.

Karabulut-Bulan, O.; Bolkent, S.; Yanardag, R. \& Bilgin-Sokmen, B. The role of vitamin $C$, vitamin $\mathrm{E}$, and selenium on cadmium-induced renal toxicity of rats. Drug Chem. Toxicol., 31(4):413-26, 2008.

Klayman, D. L. Qinghaosu (artemisinin): an antimalarial drug from China. Science, 228(4703):1049-55, 1985.

Kumar, V.; Abbas, A.; Fausto, N. \& Robbins, C. Pathologic Basis of Disease. $7^{\text {th }}$ ed. Philadelphia (PA), Elsevier Saunders, 2004. pp.955-1021.

Lai, H. C.; Singh, N. P. \& Sasaki, T. Development of artemisinin compounds for cancer treatment. Investig. New Drugs, 31(1):230-46, 2013.

Mahan, L. K.; Escott-Stump, S.; Raymond, J. L. \& Krause, M. V. Krause's Food and the Nutrition Care Process. $13^{\text {th }}$ ed. St. Louis (Mo.), Elsevier/ Saunders, 2012.

Markowitz, G. S.; Radhakrishnan, J.; Kambham, N.; Valeri, A. M.; Hines, W. H. \& D'Agati, V. D. Lithium nephrotoxicity: a progressive combined glomerular and tubulointerstitial nephropathy. J. Am. Soc. Nephrol., 11(8):1439-48, 2000.

Meshnick, S. R. Artemisinin: mechanisms of action, resistance and toxicity. Int. J. Parasitol., 332(13):1655-60, 2002.

Meshnick, S. R.; Tsang, T. W.; Lin, F. B.; Pan, H. Z.; Chang, C. N.; Kuypers, F.; Chiu, D. \& Lubin, B. Activated oxygen mediates the antimalarial activity of Qinghaosu. Prog. Clin. Biol. Res., 313:95-104, 1989.

Nasr, A. Y. \& Saleh, H. A. Aged garlic extract protects against oxidative stress and renal changes in cisplatin-treated adult male rats. Cancer Cell Int., 14(1):92, 2014. 
Quezada, C.; Alarcón, S.; Jaramillo, C.; Muñoz, D.; Oyarzún, C. \& San Martín, R. Targeting adenosine signaling to treatment of diabetic nephropathy. Curr. Drug Targets; 14(4):490-6, 2013.

Rao, K.; Sethi, K.; Ischia, J.; Gibson, L.; Galea, L.; Xiao, L.; Yim, M.; Chang, M.; Papa, N.; Bolton, D.; et al. Protective effect of zinc preconditioning against renal ischemia reperfusion injury is dose dependent. PloS One, 12(7):e0180028, 2017.

Saadi, L.; Lebaili, N. \& Benyoussi, M. Exploration of cytotoxic effect of Malathion on some rat organs structure. Commun. Agric. Appl. Biol. Sci., 73(4):875-81, 2008

Scott, M. D.; Meshnick, S. R.; Williams, R. A.; Chiu, D. T.; Pan, H. C.; Lubin, B. H. \& Kuypers, F. A. Qinghaosu-mediated oxidation in normal and abnormal erythrocytes. J. Lab. Clin. Med., 114(4):401-6, 1989.

Shamsi, M. B.; Venkatesh, S.; Kumar, R.; Gupta, N. P.; Malhotra, N.; Singh, N.; Mittal, S.; Arora, S.; Arya, D. S.; Talwar, P.; et al. Antioxidant levels in blood and seminal plasma and their impact on sperm parameters in infertile men. Indian J. Biochem. Biophys., 47(1):38-43, 2010.

Spek, C. A.; Brüggemann, L. W. \& Borensztajn, K. S. Protease-activated receptor 2 blocking peptide counteracts endotoxin-induced inflammation and coagulation and ameliorates renal fibrin deposition in a rat model of acute renal failure. Shock, 33(3):339-40, 2010.

Tesar, V.; Zimma, T.; Poledne, R.; Stejskalová, A.; Stípek, S. \& Te mínová, $\mathrm{J}$. The effect of chronic administration of ethanol on experimental adriamycin nephropathy. Cas. Lek. Cesk., 133(9):268-71, 1994.

Uz, Y. H. \& Uygun, M Structural effects of vitamin E on proximal tubule and interstitium in a rat model of cyclosporin A nephrotoxicity. Pak. $J$. Biol. Sci., 8(12):1712-9, 2005.

Vielhauer, V.; Anders, H. J.; Mack, M.; Cihak, J.; Strutz, F.; Stangassinger, M.; Luckow, B.; Gröne, H. J. \& Schlöndorff, D. Obstructive nephropathy in the mouse: progressive fibrosis correlates with tubulointerstitial chemokine expression and accumulation of CC chemokine receptor 2- and 5-positive leukocytes. J. Am. Soc. Nephrol., 12(6):1173-87, 2001.

Walker, P. D.; Barri, Y. \& Shah, S. V. Oxidant mechanisms in gentamicin nephrotoxicity. Ren. Fail., 21(3-4):433-42, 1999.

Wang, Q. L.; Yuan, J. L.; Tao, Y. Y.; Zhang, Y.; Liu, P. \& Liu, C. H. Fuzheng Huayu recipe and vitamin $\mathrm{E}$ reverse renal interstitial fibrosis through counteracting TGF-beta1-induced epithelial-to-mesenchymal transition. J. Ethnopharmacol., 127(3):631-40, 2010.

Xiao, S. H.; Yang, Y.; You, Q.; Utzinger, J.; Guo, H.; Peiying, J.; Mei, J.; Guo, J.; Bergquist, R. \& Tanner, M. Potential long-term toxicity of repeated orally administered doses of artemether in rats. Am. J. Trop. Med. Hyg., 66(1):30-4, 2002.

Zager, R. A. \& Burkhart, K. Myoglobin toxicity in proximal human kidney cells: roles of $\mathrm{Fe}, \mathrm{Ca} 2+, \mathrm{H} 2 \mathrm{O} 2$, and terminal mitochondrial electron transport. Kidney Int., 51(3):728-38, 1997.

Zhang, F.; Gosser Jr., D. K. \& Meshnick, S. R. Hemin-catalyzed decomposition of artemisinin (Qinghaosu). Biochem. Pharmacol., 43(8):1805-9, 1992.

\author{
Corresponding author: \\ Dr. Refaat A. Eid \\ Department of Pathology \\ College of Medicine \\ King Khalid University \\ Abha \\ SAUDI ARABIA
}

Email: refaat_eid@yahoo.com

Received: 05-08-2019

Accepted: 08-10-2019 